\title{
STRATEGI PENINGKATAN KINERJA MANAJEMEN SEKOLAH PADA SMAK SWASTA FRATERAN NDOA ENDE
}

\author{
Gabriel Tanusi,Angela Merici Gerha \\ Universitas Flores Ende \\ gebytanusi@gmail.com, gerhaangela1@gmail.com
}

\begin{abstract}
This study aims to identify and analyze the management performance of SMAK Frateran Ndao using a balanced scorecard approach in developing future strategies. This type of research is descriptive quantitative. Data collection techniques using documentation, questionnaires and interviews. The results showed that the financial perspective was very economical, effective and inefficient. Costumer perspective is categorized as satisfied, the internal business process perspective is categorized as very good, the growth and learning perspective is categorized as satisfied. The strategy developed : the use of finance according to the RABS, increasing the amount of pension salaries for teachers and education personnel, increasing the cost of renovating school facilities and infrastructure, increasing tuition bills, increasing teacher competence, increasing student achievement in academic and non-academic fields, holding school cooperation, increasing promotion through school websites, improve cooperation with parents, alumni, and other parties
\end{abstract}

Keywords: performance measurements, financial perspective, customer perspective, internal business perspective, growth and learning perspective

\begin{abstract}
ABSTRAK
Penelitian ini bertujuan untuk mengetahui dan menganalisis kinerja manajemen SMAK Frateran Ndao menggunakan pendekatan balanced scorecard dalam mengembangkan strategi dimasa akan datang. Jenis penelitian ini adalah deskriptif kuantitatif. Teknik pengumpulan data menggunakan dokumentasi, kuesioner dan wawancara. Hasil penelitian menunjukkan perspektif keuangan sangat ekonomis, efektif, tidak efisien. Perspektif pelanggan dikategorikan puas, perspektif proses bisnis internal dikategorikan sangat baik, perspektif pertumbuhan dan pembelajaran dikategorikan puas. Strategi yang dikembangkan : penggunaan keuangan sesuai RABS, meningkatkan jumlah gaji pensiun guru dan tenaga kependidikan, meningkatkan biaya peremajaan sarana dan prasarana sekolah, meningkatkan tagihan SPP, meningkatkan kompetensi guru, meningkatkan prestasi siswa dibidang akademik dan non akademik, mengadakan koperasi sekolah, meningkatkan promosi melalui website sekolah, menigkatkan kerjasama dengan orang tua, alumni, dan pihak lain
\end{abstract}

kata kunci : pengukuran kinerja, perspektif keuangan, perspektif pelanggan, perspektif bisnis internal, perspektif pertumbuhan dan pembelajaran 


\section{A. LATAR BELAKANG}

Manajemen berbasis sekolah merupakan salah satu model pelaksanaan otonomi dibidang pendidikan. Sekolah yang menerapkan model manajemen berbasis sekolah akan memiliki kewenangan untuk melakukan kreasi, inovasi dan improvisasi dalam mewujudkan pendidikan yang berkualitas. Sistem manajemen sekolah secara langsung akan mempengaruhi dan menentukan efektif tidaknya penerapan kurikulum, ketersediaan sarana prasarana, ketersediaan sumber daya manusia (guru dan pegawai), oleh karena itu upaya meningkatkan kualitas pendidikan dimulai dari penataan manajemen sekolah, peningkatan kompetensi guru maupun pengembangan sumber belajar (Suyatno, 2017).

Sudana (2017) mengemukakan hambatan utama dalam pengembangan Pendidikan bukan semata mata pada aspek keuangan, tetapi bertumpu pada aspek manajemen, oleh karena itu dalam memperbaiki mutu Pendidikan harus dimulai dari perbaikan manajemen pendidikan dengan memperhatikan berbagai hambatan dalam manajemen berbasis sekolah.

SMA Katolik Frateran Ndao Ende (SMAK Frateran Ndao) merupakan salah satu SMA Swasta yang dikelola Yayasan Mardiwiyata, memiliki nilai Akreditasi A dan sebagai sekolah rujukan nasional. Visi dari SMAK Frateran Ndao adalah "terwujudnya pribadi yang religius, cerdas, terampil, tangguh, unggul, mandiri, dan gotong royong berintegritas dalam Iptek, berwawasan nasional dengan semangat hati yang jujur", dan taglinenya adalah "Raih prestasi, jujur harga mati". SMAK Frateran Ndao memiliki 640 siswa yang terbagi dalam 21 rombongan belajar dengan jumlah guru sebanyak 50 0rang dan jumlah tenaga kependidikan sebanyak 16 orang (http://dapo.kemendikbud.go.id / data pokok SMAK Frateran Ndao 2020)

Penilaian kinerja manajemen sekolah dianalisis menggunakan pendekatan balanced scorecard, yang merupakan sistem perencanaan manajemen dan penilaian kinerja yang dikembangkan oleh Kaplan dan
Norton pada tahun 1992 dalam jurnal Harvard Review yang berjudul Balanced scorecard measure that drive performance. Balanced scorecard tidak hanya menilai kinerja identitas dari aspek keuangan saja, namun dengan menerjemahkan visi dan strategi entitas kedalam berbagai tujuan dan ukuran yang tersusun dalam empat perspektif yaitu perspektif keuangan, perspektif pelanggan, perspektif proses bisnis internal, serta perspektif pertumbuhan dan pembelajaran (Daud et al., 2018)

Balanced scorecard menilai kinerja suatu entitas dari aspek keuangan, pelanggan, bisnis internal, pertumbuhan dan pembelajaran sehingga dapat memberikan pandangan yang seimbang dalam menilai kinerja manajemen suatu organisasi, antara lain (Soputro et al., 2016) :

1. Perspektíf keuangan (fínancíal), yang diukur dari pernyataan guru dan pegawai tentang alur keuangan sekolah

2. Perspektíf pelanggan (costomer), yang diukur dari kepuasaan peserta didik SMAK Frateran Ndao terhadap layanan yang diberikan .

3. Perspektíf proses bísnís internal (bussines internal process), yang diukur dari pernyataan guru dan pegawai tentang proses internal sekolah.

4. Perspektíf pembelajaran dan pertumbuhan (learníng and growth), yang diukur dari guru dan pegawai dalam pelatihan dan pengembangan sekolah

Tujuan pengukuran dalam balanced scorecard bukan hanya penggabungan darí ukuran keuangan dan non keuangan yang ada, melaínkan merupakan hasíl suatu proses top down berdasarkan vísí dan strategí darí satu unít organísasí. Balanced scorecard sangat bermanfaat bagí organísasí pendídíkan dímana fokus díletakan pada strategí dan mísí sekolah. Keempat perspektíf balanced scorecard dalam penerapannya dítempatkan dalam kerangka yang teríntegrasí dan seímbang guna mengevaluasí dan memperbaíkí kínerja SMA Katolík Frateran Ndao Ende secara komperhensíf dapat dilhat pada tabel berikut : 


\begin{tabular}{|c|c|}
\hline Perspektíf & Índíkator \\
\hline $\begin{array}{l}\text { Penyediaan anggaran } \\
\text { secara rutin }\end{array}$ & Ekonomis, efisien, dan efektif. \\
\hline Kepuasan pelanggan & $\begin{array}{l}\text { Tingkat kualitas pelayanan dan kepuasan } \\
\text { siswa. }\end{array}$ \\
\hline $\begin{array}{l}\text { inovasi, proses, dan } \\
\text { pelayanan purna jual } \\
\text { (alumni) }\end{array}$ & $\begin{array}{l}\text { Inovasi kurikulum, standar proses, pendidik } \\
\text { dan kependidikan, sarana dan prasarana, } \\
\text { kompetensi lulusan, penilaian pendidikan, dan } \\
\text { pengelolaan }\end{array}$ \\
\hline $\begin{array}{l}\text { Kepuasan guru dan } \\
\text { pegawai serta sistem } \\
\text { informasi sekolah }\end{array}$ & $\begin{array}{l}\text { Kepuasan kerja dan kemampuan sistem } \\
\text { informasi }\end{array}$ \\
\hline $\begin{array}{l}\text { Pengukuran kinerja manajemen } \\
\text { sekolah selama ini berdasarkan pada } \\
\text { delapan standar nasinal pendidikan yang } \\
\text { meliputi standar isi kurikulum, standar } \\
\text { proses, standar kompetensi lulusan, standar } \\
\text { pendidik dan kependidikan, standar sarana } \\
\text { dan prasarana, standar pengelolaan, standar } \\
\text { pembiayaan, dan standar penilaian } \\
\text { pendidikan yang meliputi evaluasi, }\end{array}$ & $\begin{array}{l}\text { Suyatno (2017), menyatakan bahwa } \\
\text { dengan pengukuran kinerja yang } \\
\text { komprehensif, balanced scorecard dapat } \\
\text { diimplementasikan pada berbagai organisasi } \\
\text { kelas dunia sebagai sistem manajemen } \\
\text { strategis dan bahkan sebagai pemandu serta } \\
\text { pendorong proses perubahan manajemen dan } \\
\text { kultur organisasi termasuk implementasi } \\
\text { pada manajemen berbasis sekolah }\end{array}$ \\
\hline
\end{tabular}

akreditasi, sertfikasi, penjaminan mutu (Lubis,2016). Penilaian kinerja sekolah tersebut belum optimal sehingga perlu dilakukan penilaian kinerja menggunakan pendekatan balanced scorecard.

\section{B. TUJUAN PENELITIAN}

Penelitian ini bertujuan untuk mengetahui dan menganalisis kinerja manajemen SMAK Frateran Ndao ditinjau dari perspektif keuangan, pelanggan, proses bisnis internal, pertumbuhan dan pembelajaran dengan menggunakan pendekatan balanced scorecard. Hasil analisis balanced scorecard kemudian dlakukan identifikasi terhadap kekuatan dan kelemahan yang dimiliki sekolah serta peluang dan ancaman yang dihadapi dalam mengembangkan strategi dimasa akan datang menggunakan analisis SWOT

\section{METODE PENELÍTÍAN}

Penelítían íní termasuk jenis penelítían deskríptíf, yang bertujuan untuk menjelaskan karakteristik suatu fenomena yang dapat digunakan sebagai dasar pembuatan keputusan untuk memecahkan masalah - masalah organisasi (Indriantoro dan Supomo, 2014). Dalam kaitan dengan penelitian ini untuk menggambarkan kinerja manajemen SMAK Frateran Ndao dengan

pendekatan balanced scorecard, hasil analisis tersebut akan ditemukan kekuatan, kelemahan, peluang dan ancaman sehingga dapat dirumuskan strategi dalam rangka meningkatkan kinerja sekolah. Populasi dalam penelitian ini mempertimbangkan lamanya masa sekolah, sehingga diambil siswa kelas XI dan XII berjumlah 499 siswa, sedangkan untuk guru dan pegawai berjumlah 62 orang. Teknik penentuan sampel untuk siswa menggunakan rumus slovin dengan jumlah sampel sebanyak 83 orang dengan tingkat kesalahan $10 \%$ dan untuk guru dan pegawai sebanyak 62 orang. Teknik pengumpulan data menggunakan dokumentasi, kuesioner dan wawancara. Teknik analisis data menggunakan analisis balanced scorecard dan analisis SWOT

\section{HASIL DAN PEMBAHASAN}

Hasil pengukuran kinerja manajemen sekolah pada SMAK Frateran Ndao menggunakan pendekatan balanced scorecard dapat dilihat pada tabel berikut : 


\begin{tabular}{|c|c|c|c|c|}
\hline No & Perspektif & Indikator & Skor & Kategori \\
\hline \multirow[t]{2}{*}{ I } & Keuangan & $\begin{array}{l}\text { Ekonomis } \\
\text { Efisien } \\
\text { Efektif }\end{array}$ & $\begin{array}{l}3 \\
5 \\
3\end{array}$ & $\begin{array}{l}\text { Cukup ekonomis } \\
\text { Cukup efisien } \\
\text { Sangat efektif }\end{array}$ \\
\hline & Jumlah skor & & 11 & \\
\hline \multirow[t]{2}{*}{2} & Pelanggan & $\begin{array}{l}\text { Kualitas layanan } \\
\text { Kepuasan pelanggan }\end{array}$ & $\begin{array}{l}5 \\
5\end{array}$ & $\begin{array}{l}\text { Sangat puas } \\
\text { Sangat puas }\end{array}$ \\
\hline & Jumlah skor & & 10 & \\
\hline \multirow[t]{2}{*}{3} & Bisnis Internal & $\begin{array}{l}\text { a. Ínovasí kurikulum (standar isi) } \\
\text { b. Proses } \\
\text { 1). Standar proses } \\
\text { 2). Standar pendidik \& kependidikan } \\
\text { 3). Standar Sarana dan Prasarana } \\
\text { 4). Standar Kompetensí Lulusan } \\
\text { 5). Standar Penílaían Pendídíkan } \\
\text { 6). Standar Pengelolaaan } \\
\text { c. Layanan purna jual } \\
\text { 1). Website sekolah } \\
\text { 2). Organisasi alumni } \\
\text { 3). Data telusur alumni }\end{array}$ & $\begin{array}{l}4 \\
4 \\
5 \\
5 \\
5 \\
5 \\
5 \\
\\
5 \\
5 \\
4\end{array}$ & $\begin{array}{l}\text { Baik } \\
\text { Baik } \\
\text { Sangat baik } \\
\text { Sangat baik } \\
\text { Sangat baik } \\
\text { Sangat baik } \\
\text { Sangat baik } \\
\text { Sangat baik } \\
\text { Sangat baik } \\
\text { Baik }\end{array}$ \\
\hline & Jumlah skor & & 47 & \\
\hline \multirow[t]{3}{*}{4} & $\begin{array}{l}\text { Pertumbuhan \& } \\
\text { pembelajaran }\end{array}$ & $\begin{array}{l}\text { a. Kepuasaan kerja } \\
\text { b. Kemampuan sistem informasi }\end{array}$ & $\begin{array}{l}3 \\
4\end{array}$ & $\begin{array}{l}\text { Cukup puas } \\
\text { Puas }\end{array}$ \\
\hline & Jumlah skor & & 7 & \\
\hline & $\begin{array}{l}\text { Jumlah skor } \\
\text { keseluruhan }\end{array}$ & & 75 & \\
\hline
\end{tabular}

Berdasarkan tabel diatas terlihat bahwa total bobot skor hasil pengukuran kinerja manajemen SMAK Frateran Ndao dengan menggunakan balanced scorecard nilai skornya sebesar 75 dengan penyebarannya : skor perspektif keuangan sebesar 11, skor perspektif pelanggan sebesar 10, skor perspektif bisnis internal sebesar 47, skor perspektif pertumbuhan dan pembelajaran sebesar 7, Hasil pengukuran total skor kinerja manajemen SMAK Frateran Ndao selanjutnya dibandingkan dengan skala nilai akhir balanced scorecard seperti terlihat pada tabel berikut :

\begin{tabular}{|c|c|l|}
\hline Nilai skor & Skala & Kategori \\
\hline $17-30$ & 1 & Sangat tidak baik \\
\hline $31-44$ & 2 & Tidak baik \\
\hline $45-58$ & 3 & Cukup baik \\
\hline $59-72$ & 4 & Baik \\
\hline $73-85$ & 5 & Sangat baik \\
\hline
\end{tabular}

Sumber : Sugiono, 2010

Berdasarkan standar penilaian diatas, pengkuran kinerja SMAK Frateran Ndao menggunakan balanced scorecard berada pada posisi sangat baik dengan jumlah skor keseluruhan sebanyak 75 (Tujuh puluh lima). Hasil temuan penelitian, kemudian dilakukan kajian faktor terhadap faktor lingkungan internal sekolah sehingga ditemukan adanya kekuatan dan kelemahan yang dimiliki serta kajian terhadap faktor lingkungan eksternal sekolah sehingga akan ditemukan adanya peluang dan ancaman yang dihadapi dengan menggunakan analisis strenghts, weaknesses, opportunities, threaths (SWOT) dalam merumuskan strategi peningkattan kinerja sekolah. Suyatno (dalam Dally 2017) mengatakan pengukuran kinerja dengan pendekatan balanced scorecard dapat digunakan sebagai dasar penyusunan perencanaan strategis sekolah dalam peningkatan kinerja. Hasil temuan dengan menggunakan analisis balanced scorecard dan analisis Swot dapat dilhat pada tabel berikut : 


\begin{tabular}{|c|c|c|c|c|c|c|c|c|}
\hline \multirow[t]{2}{*}{ Rumusan Temuan } & \multicolumn{4}{|c|}{ Analisa BSC } & \multicolumn{4}{|c|}{ Analisa SWOT } \\
\hline & $\mathrm{K}$ & $\mathrm{P}$ & PBI & $\mathrm{P} \& \mathrm{P}$ & $\mathrm{S}$ & $\mathrm{W}$ & $\mathrm{O}$ & $\mathrm{T}$ \\
\hline \multicolumn{9}{|l|}{ Kondisi Internal } \\
\hline Memiliki kemampuan finansial yang baik & $*$ & & & & $*$ & & & \\
\hline Memiilki gaji pensiun bagi guru dan pegawai & $*$ & & & & $*$ & & & \\
\hline Biaya pemeliharaan & * & & & & $*$ & & & \\
\hline Nilai akreditasi A dan sekolah rujukan nasional & & * & & & $*$ & & & \\
\hline Menerapkan kurikulum 2013 sesuai standar pemerintah & & $*$ & & & $*$ & & & \\
\hline Tenaga pengajar berkualifikasi Sarjana dan Magister & & & $*$ & & $*$ & & & \\
\hline Memiliki program pertukaran pelajar ke luar negeri & & & $*$ & & $*$ & & & \\
\hline Memiliki prestasi dibidang akademik dan non akademik & & & $*$ & & $*$ & & & \\
\hline Memiliki standar disiplin yang tinggi & & & $*$ & & $*$ & & & \\
\hline Memiliki sarana dan prasarana yang memadai & & & $*$ & & $*$ & & & \\
\hline Memiliki ikatan alumni & & & $*$ & & * & & & \\
\hline Belum memiliki koperasi sekolah & & & & $*$ & & $*$ & & \\
\hline Belum banyak ruang kelas dilengkapi TIK & & & & $*$ & & $*$ & & \\
\hline \multicolumn{9}{|l|}{ Kondisi Eksternal } \\
\hline Uang SPP siswa terjangkau & $*$ & & & & & & $*$ & \\
\hline Adanya dana bos dari pemerintah & $*$ & & & & & & $*$ & \\
\hline Tersedianya website sekolah & & & $*$ & & & & $*$ & \\
\hline Banyak siswa berminat masuk SMAK Frateran Ndao & & $*$ & & & & & $*$ & \\
\hline Adanya dukungan dari orang tua & & $*$ & & & & & $*$ & \\
\hline Adanya kemitraan dengan pihak lain & & * & & & & & $*$ & \\
\hline Adanya kerjasama dengan alumni & & & $*$ & & & & $*$ & \\
\hline Banyak SMA sebagai alternatif pilihan bagi siswa & & $*$ & & & & & & * \\
\hline Kebijakan pemerintah tentang rombongan belajar & & & $*$ & & & & & $*$ \\
\hline $\begin{array}{l}\text { Bersarkan hasil analisis swot } \\
\text { balanced scoredcard diatas, disusun } \\
\text { pengembangan strategi dalam meningkatkan } \\
\text { kinerja SMAK Frateran Ndao sebagai } \\
\text { berikut : menggunakan keuangan sesuai } \\
\text { RABS, meningkatkan besarnya jumlah gaji } \\
\text { pensiun untuk guru dan pegawai sehingga } \\
\text { mereka memiliki loyalitas yang tinggi } \\
\text { terhadap sekolah, meningkatkan biaya } \\
\text { peremajaan sarana dan prasarana sekolah, } \\
\text { meningkatkan tagihan SPP kepada orang tua } \\
\text { siswa, meningkatkan kompetensi guru }\end{array}$ & $\begin{array}{l}\text { mer } \\
\text { aka } \\
\text { mer } \\
\text { sain } \\
\text { pidc } \\
\text { perl } \\
\text { kese } \\
\text { seb } \\
\text { khu } \\
\text { mer } \\
\text { web } \\
\text { den }\end{array}$ & $\begin{array}{l}\text { ingk } \\
\text { emil } \\
\text { giku } \\
\text {, lo } \\
\text { to, } \\
\text { mba } \\
\text { nian, } \\
\text { gai } \\
\text { usny }\end{array}$ & $\begin{array}{l}\text { an p } \\
\text { dan } \\
\text { erbag } \\
\text { a deb } \\
\text { erbag } \\
\text { dib } \\
\text { nenga } \\
\text { dia } \\
\text { mata } \\
\text { an p } \\
\text { xolah, } \\
\text { g tua, }\end{array}$ & $\begin{array}{l}\text { tasi } \\
\text { on aka } \\
\text { even se } \\
\text { bahasa } \\
\text { perta } \\
\text { ng ol } \\
\text { kan kc } \\
\text { nbelajar } \\
\text { lajaran } \\
\text { mosi s } \\
\text { menigka } \\
\text { umni, da }\end{array}$ & $\begin{array}{l}\text { wa } \\
\text { emi } \\
\text { erti } \\
\text { ingg } \\
\text { ding } \\
\text { h }\end{array}$ & $\begin{array}{l}\text { dibi } \\
\text { de } \\
\text { olimp } \\
\text { is, lo } \\
\text { an } \\
\text { aga } \\
\text { sek } \\
\text { gi } \\
\text { ausal } \\
\text { me } \\
\text { kerja } \\
\text { k lain }\end{array}$ & $\begin{array}{l}\text { ang } \\
\text { gan } \\
\text { ade } \\
\text { nba } \\
\text { dan } \\
\text { dan } \\
\text { lah } \\
\text { swa } \\
\text { alui } \\
\text { ama }\end{array}$ & \\
\hline
\end{tabular}
melalui pendidikan dan pelatihan, Image positif di mata masyarakat

\section{KESIMPULAN}

KemajBerdasarkan hasil pengukuran kinerja manajemen SMAK Frateran Ndao menggunakan balanced scorecard dengan empat perspektif : perspektif keuangan menunjukan pengelolaan keuangan sekolah sangat ekonomis, efektif, namun tidak efisien. Perpektif pelanggan menunjukan tingkat kepuasan siswa terhadap layanan

yang diberikan sebésar 74,40\% (skala *) dengan kategori puas. Perspektif proses bisnis internal yang meliputi inovasi, proses pengelolaan pendidikan dan layanan purna jual (alumni) memiliki skor 47 dengan kategori sangat baik. perspektif pertumbuhan dan pembelajaran menunjukan kepuasan guru dan tenaga kependidikan sebesar 73,33\% (skala 4) kategori puas. 
Berdasarkan hasil analisis SWOT balanced scored card, dapat dikembangkan strategi antara lain : penggunaan keuangan disesuaikan dengan RABS, meningkatkan besarnya jumlah gaji pensiun unuk guru dan pegawai, meningkatkan biaya peremajaan sarana dan prasarana sekolah, meningkatkan tagihan SPP kepada orang tua siswa, meningkatkan kompetensi guru melalui pendidikan dan pelatihan, meningkatkan prestasi siswa dibidang akademik dan non akademik, mengadakan koperasi sekolah, meningkatkan promosi sekolah melalui website sekolah serta meningkatkan kerjasama dengan orang tua, alumni, dan pihak lain

\section{DAFTAR REFERENSI}

Daud, M., Anwar, R., \& Abdul, K. (2018). Strategi Peningkatan Kinerja Sekolah SMA Berbasis Balanced Scorecard Pada Yayasan Pendidikan Madania Indonesia. Manajemen, 9(1).

Indriantoro, \& Supomo. (2014). Metodologi Penelitian Bisnis (6th ed.).
Lubis. Asri (2016). Pelaksanaan Standar Nasional Dalam Dunia Pendidikan.

https//dapo. kemdikbud.go.id Data pokok SMAK Frateran Ndao (diunduh 20 Mei 2021)

Soputro, S. N., Yulia, Y., \& Wibowo, A. (2016). Analisis Kinerja SMA Katolik Santo Augustinus dengan Metode Balanced Scorecard. Jurnal Infra.

Sudana. (2017). Implementasi Balanced Scorecard dalam Pengukuran Kinerja Manajemen Berbasis Sekolah. Manajemen Pendidikan.

Sugiono. (2010). Metode Penelitían Bísnís (Pendekatan Kuantítatíf, Kualítatíf dan $R \& D)$.

Suyatno. (2017). Implementasi Balanced Scorecard dalam Pengukuran Kinerja Manajemen Berbasis Sekolah. Manajemen Pendidikan, 6(1). 